\section{Biomass production of Populus nigra L. clones grown in short rotation coppice systems in three different environments over four rotations}

\author{
Vojtěch Benetka, Kateřina Novotná, Petra Štochlová
}

Three clones of black poplar and a hybrid poplar clone, "NE-42", were trialled in a short rotation coppice system. The trial was replicated in three sites located in the Czech Republic with distinctly different soils and climates which were judged to be respectively favorable, unfavorable and marginal for growing black poplar. In the marginal and unfavorable sites the planting density was 2222 trees ha-1 and in optimal conditions 7407 trees ha-1. The aim of the trial was: (1) to test the performance of black poplar clones as a possible replacement for commercial hybrid poplars in areas where the genetic integrity of wild black poplar populations is under threat; $(2)$ to test the range of conditions in which it is possible to grow black poplar and its suitability for utilizing marginal agricultural land; and (3) to measure the potential yield of black poplar clones grown in these conditions. During four harvests at three-year intervals, the following parameters were measured: plant mortality, number of shoots, thickness of shoots, the total cross-sectional area (TCA) of all shoots, the dry matter weight of individual plants (DMIP) and the dry matter yields per hectare. The differences observed between "NE-42" and the best black poplar clone decreased as conditions became more favorable. During the fourth harvest at the unfavorable site for growing poplars, the yield of dry biomass was $11.7 \mathrm{t} \mathrm{ha}^{-1} \mathrm{yr}^{-1}$ for "NE-42" compared to $3.7 \mathrm{t} \mathrm{ha}^{-1} \mathrm{yr}^{-1}$ for the best black poplar clone. In marginal conditions the yields were 11.8 and $9.9 \mathrm{t} \mathrm{ha}^{-1} \mathrm{yr}^{-1}$ respectively, and in the favorable conditions there was no statistically significant difference, being 15.9 and $13.2 \mathrm{t} \mathrm{ha}^{-1} \mathrm{yr}^{-1}$, respectively. The higher yield of "NE42" was due to the higher proportion of thicker shoots or, alternatively, lower plant mortality. The observed TCA was highly correlated with DMIP $\left(r_{s}=0.87\right)$ and dry biomass yield $\left(r_{\mathrm{s}}=0.48\right)$. It was demonstrated that black poplar can be successfully grown in marginal conditions on land which otherwise would not be especially suitable for agricultural production, and also in areas where the genetic purity of native populations of black poplar is threatened by the spread of commercially grown hybrid poplars.

Keywords: Growing Conditions, Fast-growing Trees, NE-42, Number of Shoots, Stool Mortality, Yield

\section{Introduction}

The cultivation of fast-growing trees in short rotation coppice (SRC) systems has increased in recent years mainly because it provides a source of renewable energy. Today such kind of farming covers thousands of hectares in Europe (Venendaal et al. 1997, Langeveld et al. 2012), with the most commonly grown species being willows (Salix) and poplars (Populus - Herve \& Ceulemans 1996, Verwijst 2001, Langeveld et al. 2012). This trend has also been accompanied by extensive plant breeding (Stanton et al. 2010, Karp et al. 2011), but the selection of new cultivars has been based almost entirely on inter-specific crosses. In Europe new poplar hybrids are derived mainly from crosses between $P$. nigra and $P$. deltoides
Bart. ex Marsh. (Bisoffi \& Gullberg 1996) or $P$. nigra and P. maximowiczii Henry (Stanton et al. 2010). Such hybrids are capable of successfully pollinating and breeding with wild populations of $P$. nigra, and consequently are a threat to the genetic purity of this indigenous species (Cagelli \& Lefèvre 1995, Benetka et al. 2002, Smulders et al. 2008). The spread of these hybrids and the contamination of $P$. nigra gene pools has lead in certain places to restrictions being placed on their cultivation. This raises the question if it is possible or not to develop commercially acceptable clones of pure-bred black poplars to grow in place of the undesirable interspecific hybrids. According to several published results, many clones derived from genetically pure species of the $\square$ Silva Tarouca Research Institute for Landscape and Ornamental Gardening, Publ. Res. Inst., Kvetnové námestí 391, CZ-252 43 Pruhonice (Czech Republic)

@ Petra Štochlová (stochlova@vukoz.cz) Received: Oct 23, 2013 - Accepted: Dec 19, 2013

Citation: Benetka V, Novotná K, Štochlová P, 2014. Biomass production of Populus nigra $\mathrm{L}$. clones grown in short rotation coppice systems in three different environments over four rotations. iForest 7 : 233-239 [online 2014-03-10] URL: http:// www. sisef. it/iforest/contents/?id=ifor1162007

\section{Communicated by: Gianfranco Minotta}

genus Populus show yields comparable with the inter-specific hybrid clones. In trials with the species $P$. trichocarpa Torr. \& Gray, the pure species had similar yields to the hybrids (Rogers \& Stettler 1989). In other trials using $P$. nigra and $P$. trichocarpa, their biomass yields over four successive harvests were remarkably higher than in hybrid clones such as $P$. trichocarpa $\times P$. deltoides and $P$. deltoides $\times P$. trichocarpa (Dillen et al. 2011).

Species of the genus Populus and their hybrids can be regarded as having two main different strategies for biomass formation as for the number of shoots per plant. The first group includes $P$. trichocarpa and $P$. trichocarpa $\times P$. deltoides, which eliminate small shoots rapidly to leave just a few large dominant shoots. The second group, comprising genotypes like $P$. nigra and $P$. trichocarpa $\times$ P. balsamifera L., eliminate small shoots slowly, so maintaining many small shoots per stool (Laureysens et al. 2005, Al Afas et al. 2008). Furthermore, differences in the proportion of lateral shoots contributing to yield in P. nigra and hybrid clones have been observed as early as in the second and third harvests, when the proportion of lateral shoots can be significant (Laureysens et al. 2005, Benetka et al. 2007). In situations where there is a lower overall number of shoots it can be expected that these will be thicker. Moreover, after each harvest there is an increase in the number of shoots per plant (Strong 1989, Al Afas et al. 2008, Dillen et al. 2011) and therefore the resource demands on the site will also increase, boosting the intra-specific plant competition. However, this is off-set by the reduction of plant shoots or even plant numbers due to pathogens, shading or increased competition for resources (the self-thinning effect), which then opens up the area to be better utilized by the remaining plants (Dillen et al. 2011). The number of plants per unit area after the 
first and second rotations can be significantly reduced by plant mortality (Ceulemans \& Deraedt 1999, Laureysens et al. 2005). Large differences in mortality among the studied genotypes have been observed in experiments conducted over several rotations (Al Afas et al. 2008, Dillen et al. 2011).

SRC systems are a long-term culture which may last for up to 25 years (Dillen et al. 2011). The expression of the various yield traits, which together contribute to the final yield of biomass, is dependent on the interaction of any given genotype and its environment. It is therefore important to evaluate the performance of genotypes in the different conditions in which they will be grown. The main environmental factors to consider are levels of available light, water and soil fertility.

$P$. nigra is the principal pioneer tree species that colonizes river floodplains, wastelands and other exposed sites, where the moist, sandy soil exposed after seasona flooding provides an ideal seedbed (Dickmann \& Kuzovkina 2008). Based on an analysis of ecological requirements of $P$. nigra, optimal conditions for its growth in the Czech Republic would be provided by sites with an average annual temperature of 7.5 to $9.0^{\circ} \mathrm{C}$, a temperature in the growing season (April to September) above $14{ }^{\circ} \mathrm{C}$, with hydromorphic or semi-hydromorphic soils and a water table at a depth of 0.5 to $1.2 \mathrm{~m}$, or at a depth of only $1.0 \mathrm{~m}$ where dense vegetation prevents the full penetration of rain water. Heavy clay soils are unsuitable. Colder locations are less favorable, and those with

Tab. 1 - Description of the study localities.

\begin{tabular}{|c|c|c|c|c|}
\hline Characteristics & Year & BY & SM & RO \\
\hline \multicolumn{2}{|l|}{ Latitude $(\mathrm{N})$} & $49^{\circ} 21^{\prime}$ & $49^{\circ} 36^{\prime}$ & $50^{\circ} 03^{\prime}$ \\
\hline \multicolumn{2}{|l|}{ Longitude (E) } & $12^{\circ} 48^{\prime}$ & $14^{\circ} 36^{\prime}$ & $15^{\circ} 42^{\prime}$ \\
\hline \multicolumn{2}{|l|}{ Altitude (m a.s.1.) } & 551 & 515 & 219 \\
\hline \multicolumn{2}{|l|}{ Climatic region } & $\begin{array}{l}\text { moderately cold } \\
\text { and moist }\end{array}$ & $\begin{array}{l}\text { moderately warm } \\
\text { and moist }\end{array}$ & $\begin{array}{c}\text { warm and } \\
\text { moderately dry }\end{array}$ \\
\hline \multicolumn{2}{|c|}{$\begin{array}{l}\text { Mean temperature }>10^{\circ} \mathrm{C} \\
\text { (num. of days) }\end{array}$} & $120-140$ & $140-160$ & $160-170$ \\
\hline \multicolumn{2}{|c|}{ Mean ann. temperature $\left[{ }^{\circ} \mathrm{C}\right]$} & 5.7 & 6.8 & 8.5 \\
\hline \multicolumn{2}{|c|}{ Soil type } & Histosol & Cambisol & Alluvial soils \\
\hline \multicolumn{2}{|l|}{$\mathrm{pH} / \mathrm{CaCl}_{2}$} & 4.95 & 6.75 & 6.68 \\
\hline \multicolumn{2}{|c|}{ Plot status before the experiment } & lay fallow & farmed up & lay fallow \\
\hline \multicolumn{2}{|c|}{ Influenced by neighboring river } & yes & no & yes \\
\hline Sum of rainfall & 1999 & - & 352 & - \\
\hline \multirow[t]{12}{*}{ (Apr-Sep [mm]) } & 2000 & - & 393 & - \\
\hline & 2001 & - & 501 & - \\
\hline & 2002 & - & 548 & - \\
\hline & 2003 & - & 265 & - \\
\hline & 2004 & - & 369 & - \\
\hline & 2005 & - & 415 & - \\
\hline & 2006 & - & 635 & - \\
\hline & 2007 & - & 355 & - \\
\hline & 2008 & - & 284 & - \\
\hline & 2009 & - & 401 & - \\
\hline & 2010 & - & 506 & - \\
\hline & 2011 & - & 346 & - \\
\hline
\end{tabular}

an annual average temperature below $6{ }^{\circ} \mathrm{C}$ and temperatures during the growing season below $12{ }^{\circ} \mathrm{C}$ are unsuitable (Mottl \& Dušek 1991). However in Italy, for example, optiare a mean annual temperature of 8.5 to 17 ${ }^{\circ} \mathrm{C}$ and a summer precipitation of $100-150$ $\mathrm{mm}$ (Di Matteo et al. 2012).

Fast-growing trees in SRC systems are predominantly grown in areas of intensive agriculture. This lead to a competition between the production of food and other agricultural commodities on the one hand, and the production of biomass from fast-growing trees on the other. Trees can also be grown in conditions which are marginal for conventional agricultural activities, but perhaps the real question here is whether they can still achieve satisfactory yields in such conditions.

The aim of this study was to appraise the individual yield parameters contributing to the total yield of biomass, and compare the biomass yields of several clones of black poplar with that of the hybrid clone "NE42 ", when grown in three distinctly different environments for a total of four rotations. Further, to determine the environments in which black poplar can be successfully established and grown.

\section{Materials and methods}

\section{Locality, soil and climatic conditions}

The experiment was established in three sites in the Czech Republic, each with different soil and climatic conditions (Tab. 1). mal conditions for hybrid poplar cultivation
The first site (Smilkov - SM) represents natural conditions which can be regarded as marginal but typical for the main areas where SRC systems are used. The second site (Bystrice - BY) is located in unfavorable soil and climate conditions. After a four year delay, the third trial (Rosice - RO) was established in optimal soil and climate conditions typical for a flood plain ecosystem and therefore most favorable. Compared to the other two localities, trees were established here using more dense plantings.

\section{Materials}

Four clones of $P$. nigra (designated 107, 210,301 and 302), of the total of 29 included in a wider trial, can be found growing in all three trial localities. These clones are the offspring of individuals found in local subpopulations (Benetka et al. 2007). The first three clones of $P$. nigra $(107,210,301)$ have already been shown to be healthy and possessing good yield potential, and have been recommended for cultivation in the Czech Republic (Benetka et al. 2011b). Clone 302, on the other hand, is regarded as being one of the least productive. Clone "NE-42", an interspecific hybrid of $P$. maximowiczii $\times P$. trichocarpa, was used as a control.

\section{Organization and treatments}

Densities of 2222 plants $^{-1} a^{-1}$, with a spacing of $3 \times 1.5 \mathrm{~m}$, were employed in the less favorable (SM) and the unfavorable (BY) localities; in the RO site (favorable conditions) the planting density was increased to 7407 plants ha ${ }^{-1}$, with a tighter spacing of 2 $\times 0.67 \mathrm{~m}$. Plant densities were chosen with regard to the soil and climatic characteristics of these three localities (Tab. 1). Rainfall during the growing season (months IV-IX) was only measured at the SM site. In the localities BY and RO a crucial role was played by groundwater.

The experiment was established in 1998 at the SM and BY sites, while the RO site was planted in 2002. A randomized block design with four replications was used, with four plants of each clone per replication in the BY locality and with five plants per replication in the SM site. In the RO locality the experiment had five replications with six plants per replication. Bordering rows were planted around each experimental plot. The plots were also fenced to prevent browsing by wild animals.

The planting material was obtained by cultivating $0.2 \mathrm{~m}$-long hardwood cuttings, 5 to $6 \mathrm{~mm}$ in thickness; the resulting one-year old saplings were planted out manually, with those planted at the SM site being watered in. Using one-year old saplings, the planting densities at the beginning of the experiment were the same for each investigated clone at any given site. All plants were clipped to a height of $0.4 \mathrm{~m}$ after planting out. The SM 
site was also always fertilized after harvest, with an NPK (1:1:1) growth fertilizer at a rate of $150 \mathrm{~kg} \mathrm{ha}^{-1}$, and a herbicide applied in the spring following each harvest. Twice each summer the weeds were cut and the soil disced between the rows. At the BY and RO sites discing was omitted.

The first harvest at the BY and SM sites was carried out in February 2001, the second harvest was in March 2005, the third in March 2008 and the fourth in March 2011. At the RO site the first harvest was carried out in February 2005, the second in February 2007, the third in March 2010 and the fourth in January 2013. Plants were pruned by hand to a height of $0.1 \mathrm{~m}$ above the ground for the first harvest, but in subsequent harvests they were pruned to $0.2 \mathrm{~m}$ above the ground.

\section{Measurement}

At the end of each growing season before harvesting, growth was measured by taking the diameter of each main stem at a height of $0.5 \mathrm{~m}$ from the ground. Before the second, third and fourth harvests, all shoots thicker than $0.01 \mathrm{~m}$ were counted and their diameters measured using a digital caliper. Shoots were classified on the basis of their diamete as being "weak" (10-43 mm) or "strong" (44-95 mm). The shoot with the highest diameter was considered as a main stem. Before the fourth harvest the combined total crosssectional area of all measured shoots (TCA) was calculated and expressed as the sum total area in $\mathrm{mm}^{2}$ per plant. The TCA per 100 $\mathrm{m}^{2}$, which also indirectly took account of plant mortality, was expressed in $\mathrm{m}^{2}$.

During harvest the fresh weight biomass produced jointly from all the plants of a given clone in each replicate was weighed. To measure dry weights at the same time, a representative sample of the harvested material, including the main and lateral shoots, was taken from each replicate and weighed separately. The size of these samples ranged from 400 to $1200 \mathrm{~g}$, depending on the thickness of the shoots. The samples were dried at $105{ }^{\circ} \mathrm{C}$ until their weights stabilized. Total dry matter yields per unit area were calculated from the weight of harvested fresh biomass obtained from a given replicate multiplied by the appropriate value for the per cent dry matter and calculated for a given unit area (ha) per year. Yield is a function of the number of plants actually harvested and takes the plant mortality into account. The average dry matter weights of individual plant (DMIP) were expressed in $\mathrm{kg} \mathrm{yr}^{-1}$.

\section{Statistical analysis}

The analysis of variance (ANOVA, MANOVA) or its non-parametric homologous tests was carried out using the Statistica 8.0 statistical software package (StatSoft Inc., Tulsa, OK, USA). Clones, replicates, localities and rotations were used as independent

Tab. 2 - Percentage of surviving plants in each site before harvests.

\begin{tabular}{|c|c|c|c|c|c|c|c|c|c|c|c|c|}
\hline Locality & \multicolumn{4}{|c|}{ BY } & \multicolumn{4}{|c|}{ SM } & \multicolumn{4}{|c|}{ RO } \\
\hline Harvest & I & II & III & IV & I & II & III & IV & I & II & III & IV \\
\hline $\begin{array}{l}\text { Rotation length } \\
\text { [yrs] }\end{array}$ & 3 & 4 & 3 & 3 & 3 & 4 & 3 & 3 & 3 & 2 & 3 & 3 \\
\hline Clone & \multicolumn{4}{|c|}{$\%$} & \multicolumn{4}{|c|}{$\%$} & \multicolumn{4}{|c|}{$\%$} \\
\hline 107 & 100 & 58 & 50 & 50 & 95 & 95 & 95 & 95 & 93 & 80 & 80 & 60 \\
\hline 210 & 100 & 100 & 88 & 81 & 100 & 100 & 100 & 100 & 97 & 93 & 60 & 23 \\
\hline 301 & 83 & 83 & 75 & 67 & 95 & 95 & 95 & 95 & 97 & 93 & 77 & 10 \\
\hline 302 & 56 & 44 & 13 & 6 & 92 & 88 & 80 & 80 & 83 & 60 & 50 & 29 \\
\hline NE-42 & 100 & 100 & 94 & 94 & 100 & 100 & 100 & 100 & 97 & 90 & 87 & 63 \\
\hline
\end{tabular}

variables, and parameters such as total dry matter yields per unit area, DMIP, number of shoots per plant, TCA, and diameters of the strongest shoots were used as dependent variables. When a statistical difference was found, a post-hoc comparison was carried out using Duncan's test or multiple comparisons of mean ranks. Significant differences between individual rotations or localities were established on the basis of $t$-tests. Spearman's coefficient of rank correlation was calculated between TCA and the parameters DMIP and total biomass production. All the results are presented using a significance level of $\alpha=0.05$.

\section{Results}

Since some of the results based on the first two harvests have already been published elsewhere (Benetka et al. 2007), the results presented here are mainly those derived from the third and fourth harvests. Significantly different performances of the clones in each of the three different localities was confirmed during the fourth harvest for each of the variables considered, with the exception of the dry matter yields per unit area.

\section{Stool mortality}

The number of shoots and plants per unit area fell during the course of the four rotations, and significantly differed among sites and clones (Tab. 2).

Tab. 3 - A comparison of successive harvests in clones of black poplar and "NE-42" in each locality $(t$-tests). $(*)$ : significant differences $(\mathrm{p}<0.05)$.

\begin{tabular}{ccccccccccc}
\hline & & \multicolumn{3}{c}{ DMIP } & \multicolumn{4}{c}{ dry matter yield } & \multicolumn{3}{c}{ stool mortality } \\
\cline { 3 - 11 } Site & Clone & I \& & II \& & III \& & I \& & II \& & III \& & I \& & II \& & III \& \\
& & II & III & IV & II & III & IV & II & III & IV \\
\hline BY & 107 & 0.225 & 0.231 & 0.562 & 0.360 & 0.270 & 0.607 & 0.132 & 0.815 & 1.000 \\
& 210 & $0.037^{*}$ & $0.036^{*}$ & 0.307 & $0.037^{*}$ & 0.075 & 0.142 & 1.000 & 1.000 & 1.000 \\
& 301 & $0.005^{*}$ & 0.106 & 0.560 & $0.008^{*}$ & 0.065 & 0.247 & 1.000 & 0.725 & 0.725 \\
& NE-42 & $0.000^{*}$ & 0.870 & 0.400 & $0.000^{*}$ & 0.796 & 0.487 & 1.000 & 0.356 & 1.000 \\
\hline SM & 107 & $0.000^{*}$ & $0.029 *$ & 0.492 & $0.000^{*}$ & $0.029 *$ & 0.863 & 1.000 & 1.000 & 1.000 \\
& 210 & $0.000^{*}$ & 0.310 & 0.947 & $0.000^{*}$ & 0.310 & 0.947 & 1.000 & 1.000 & 1.000 \\
& 301 & $0.002^{*}$ & 0.249 & 0.649 & $0.005^{*}$ & 0.348 & 0.732 & 1.000 & 1.000 & 1.000 \\
& NE-42 & $0.000^{*}$ & 0.112 & 0.431 & $0.000^{*}$ & 0.112 & 0.431 & 1.000 & 1.000 & 1.000 \\
\hline RO & 107 & $0.007^{*}$ & $0.014 *$ & 0.203 & 0.119 & $0.010^{*}$ & 0.937 & 0.111 & 1.000 & 0.094 \\
& 210 & $0.003^{*}$ & 0.056 & 0.077 & $0.002^{*}$ & 0.254 & $0.042^{*}$ & 0.667 & $0.024 *$ & $0.023^{*}$ \\
& 301 & 0.293 & 0.288 & 0.401 & 0.204 & 0.773 & 0.054 & 0.545 & 0.161 & $0.001^{*}$ \\
& NE-42 & $0.007^{*}$ & 0.385 & 0.529 & $0.007^{*}$ & 0.418 & 0.825 & 0.242 & 0.545 & $0.011^{*}$ \\
\hline
\end{tabular}

At the locality with marginally suitable soils and climatic conditions (SM), and with less dense vegetation, mortality of clones was low $(0-5 \%)$, and such losses were the result of mechanical damage incurred during the year of planting. Only for clone 302, which has been shown to be unsuitable for growing in SRC, losses were high, reaching $20 \%$. There were no significant differences between "NE-42" and the black poplar clones.

In locality BY mortality of clone "NE-42" was lower $(6 \%)$, though not statistically significant. Before the fourth harvest mortality in the black poplar clones ranged from 19 to $50 \%$, although in clone 302 it was $94 \%$. The high losses were the result of unsuitable soils and climate.

In the locality RO (with dense vegetation), losses were observed for all clones, and by the time of the fourth harvest, mortality in the black poplar clones ranged from 40 to $90 \%$. In "NE-42" the mortality was $36 \%$. An increase in mortality was always observed after harvest, and was particularly significant after the third harvest (Tab. 3). At this time, the surviving plants completely shaded the ground. The dead tree stumps were also infected by Cylindrocarpon, Fusarium and Verticillium fungi (Pešková \& Soukup, personal communication), which in certain circumstances can act as facultative parasites, invading weakened plants. 
Tab. 4 - Four yield traits and differences among clones before the fourth harvest. (N): number of observations.

\begin{tabular}{|c|c|c|c|c|c|c|c|}
\hline \multirow{2}{*}{ Parameter } & \multirow{2}{*}{ Clone } & \multicolumn{2}{|r|}{ BY } & \multicolumn{2}{|r|}{ SM } & \multicolumn{2}{|c|}{ RO } \\
\hline & & $\mathbf{N}$ & mean $\pm \mathrm{SE}$ & $\mathbf{N}$ & mean $\pm \mathrm{SE}$ & $\mathbf{N}$ & mean $\pm \mathrm{SE}$ \\
\hline \multirow[t]{4}{*}{ Number of shoots } & 107 & 5 & $13.4 \pm 2.6^{b}$ & 18 & $28.4 \pm 1.6^{b}$ & 18 & $6.6 \pm 0.8^{a}$ \\
\hline & 210 & 13 & $12.5 \pm 2.1^{b}$ & 20 & $36.5 \pm 2.0^{\mathrm{a}}$ & 7 & $8.6 \pm 0.8^{a}$ \\
\hline & 301 & 8 & $22.4 \pm 2.3^{\mathrm{a}}$ & 19 & $40.5 \pm 1.6^{\mathrm{a}}$ & 3 & $6.7 \pm 3.8^{\text {a }}$ \\
\hline & $\mathrm{NE}-42$ & 15 & $10.2 \pm 1.2^{b}$ & 20 & $21.9 \pm 1.1^{\mathrm{c}}$ & 19 & $6.0 \pm 1.4^{\mathrm{a}}$ \\
\hline \multirow{4}{*}{$\begin{array}{l}\text { Diameter of the main } \\
\text { shoot }[\mathrm{mm}]\end{array}$} & 107 & 5 & $49.2 \pm 3.4^{b}$ & 18 & $57.8 \pm 1.6^{b}$ & 18 & $61.2 \pm 4.7^{\mathrm{a}}$ \\
\hline & 210 & 13 & $39.0 \pm 2.8^{\mathrm{c}}$ & 20 & $44.1 \pm 1.6^{\mathrm{c}}$ & 7 & $53.3 \pm 3.9^{\mathrm{a}}$ \\
\hline & 301 & 8 & $37.0 \pm 2.7^{\mathrm{c}}$ & 19 & $47.1 \pm 1.6^{\mathrm{c}}$ & 3 & $52.7 \pm 11.7^{\mathrm{a}}$ \\
\hline & $\mathrm{NE}-42$ & 15 & $74.3 \pm 3.1^{\mathrm{a}}$ & 20 & $65.0 \pm 1.9^{\mathrm{a}}$ & 19 & $53.7 \pm 4.3^{\mathrm{a}}$ \\
\hline \multirow{4}{*}{$\begin{array}{l}\text { Total cross-sectional } \\
\text { area of all shoots per } \\
\text { plant }\left[\mathrm{mm}^{2}\right]\end{array}$} & 107 & 5 & $8214 \pm 1659^{a b}$ & 18 & $15478 \pm 4479^{a}$ & 18 & $7042 \pm 1074^{a}$ \\
\hline & 210 & 13 & $5466 \pm 826^{b}$ & 18 & $14063 \pm 3872^{\mathrm{a}}$ & 7 & $6717 \pm 1237^{a}$ \\
\hline & 301 & 8 & $7598 \pm 1021^{a b}$ & 19 & $14371 \pm 3381^{\text {a }}$ & 3 & $5449 \pm 3280^{a}$ \\
\hline & NE-42 & 15 & $15677 \pm 1973^{\mathrm{a}}$ & 20 & $15974 \pm 3942^{\mathrm{a}}$ & 19 & $5878 \pm 964^{\mathrm{a}}$ \\
\hline \multirow{4}{*}{$\begin{array}{l}\text { Total cross-sectional } \\
\text { area of all shoots per } \\
100 \mathrm{~m}^{2}\left[\mathrm{~m}^{2}\right]\end{array}$} & 107 & 5 & $0.16 \pm 0.05^{b}$ & 18 & $0.33 \pm 0.02^{a}$ & 18 & $0.34 \pm 0.06^{\mathrm{a}}$ \\
\hline & 210 & 13 & $0.10 \pm 0.02^{b}$ & 18 & $0.31 \pm 0.02^{a}$ & 7 & $0.17 \pm 0.05^{\mathrm{a}}$ \\
\hline & 301 & 8 & $0.12 \pm 0.02^{b}$ & 19 & $0.30 \pm 0.02^{\mathrm{a}}$ & 3 & $0.07 \pm 0.04^{\mathrm{a}}$ \\
\hline & $\mathrm{NE}-42$ & 15 & $0.33 \pm 0.04^{\mathrm{a}}$ & 20 & $0.35 \pm 0.02^{a}$ & 19 & $0.29 \pm 0.05^{\mathrm{a}}$ \\
\hline
\end{tabular}
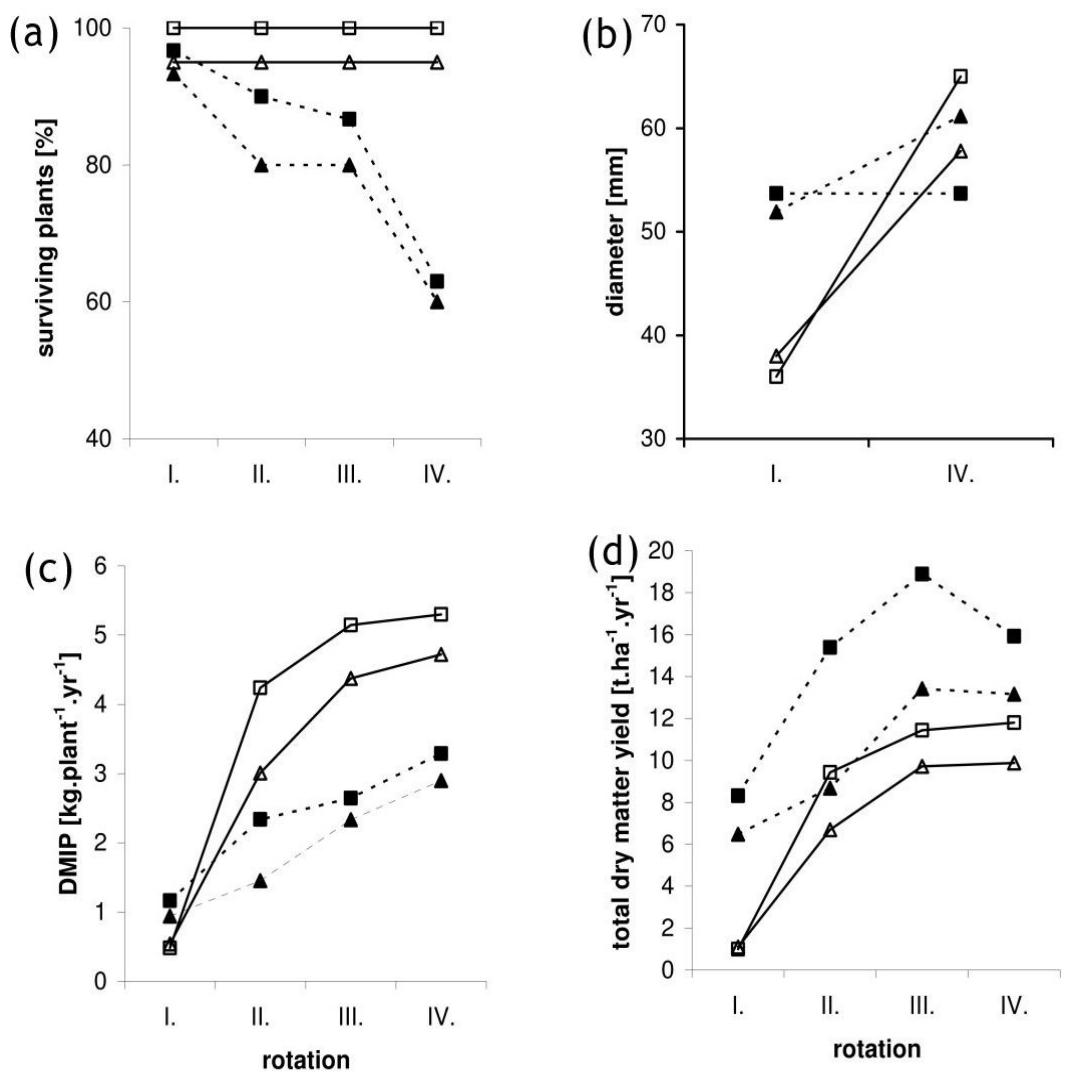

Fig. 1 - Time course of stool survival rate (a), diameter of the strongest shoot (b), dry matter weight of individual plants (c) and total dry matter yield per unit area (d) over the four rota tions of the coppiced the best P. nigra clone 107 (triangle) and "NE-42" (square) in SM (continuous line) and RO site (dotted line).

Tab. 5 - Mortality of shoots during the forth rotation with respect to the dead plants.

\begin{tabular}{lccccccccc}
\hline & \multicolumn{4}{c}{ Number of shoots per plant } & \multicolumn{3}{c}{$\begin{array}{c}\text { Shoot mortality } \\
\text { [\%] }\end{array}$} \\
\cline { 2 - 7 } Clone & \multicolumn{3}{c}{ after the III harvest } & \multicolumn{3}{c}{ before the IV harvest } & & S \\
\cline { 2 - 8 } & BY & SM & RO & BY & SM & RO & BY & SM & RO \\
\hline 107 & 18.7 & 51.9 & 8.3 & 11.2 & 28.4 & 5.4 & 40.2 & 45.2 & 35.0 \\
210 & 16.3 & 44.8 & 9.3 & 12.5 & 36.5 & 4.3 & 23.7 & 18.5 & 53.8 \\
301 & 27.4 & 59.3 & 7.8 & 22.4 & 40.5 & 1.1 & 18.3 & 31.7 & 85.7 \\
NE-42 & 16.1 & 28.5 & 6.6 & 10.2 & 21.9 & 4.6 & 36.8 & 23.3 & 30.9 \\
\hline
\end{tabular}

Clone 302 was dropped from subsequent assessments due to the unacceptably high mortality observed in all sites.

\section{Number of shoots}

The number of shoots per plant was always higher in the black poplar clones compared to "NE-42" before harvest in each locality but only statistically significantly higher in the SM locality, before the second, third and fourth harvests. In locality BY, with less suitable conditions, the average number of shoots was significantly lower than in SM. In the locality RO the number of shoots before the second harvest was low and increased very slowly in following harvests (Tab. 4).

The number of shoots developed after the third harvest in locality SM was roughly double compared to the BY site (Tab. 5). In the interval between the third and fourth harvests the number of shoots in SM and BY was reduced by a third, and in RO by half, although in locality BY the temperature and soil conditions were less favorable than RO with similar soil-water availability. As a result of the higher planting density the light conditions were worse in locality RO, which probably had an influence on the production of a lower number of shoots and their higher mortality.

The results show that the plants are able to utilize a larger area for the formation of a higher number of shoots, especially in $P$. nigra.

\section{Shoot diameter}

Leading shoot diameter before the first harvest correlated with the quality of natural conditions in P. nigra (Fig. 1b). During the fourth harvest in locality BY with sufficient ground water but unfavorable soil and temperature conditions, the leading shoot diameter was significantly greater in "NE-42" 
compared to the black poplar clones. Also, in the site SM with less available ground water and average rainfall but with higher levels of nutrients (see Tab. 1), the differences between "NE-42" and the black poplar clones were significant. In locality RO with accessible ground water, higher temperatures and fertile soils, the leading shoot diameter in "NE-42" was the same as the black poplar clones (Tab. 4).

The average shoot diameter was $30.4 \mathrm{~mm}$ in $\mathrm{RO}$, where the number of shoots was lower, $25.9 \mathrm{~mm}$ in BY and $21.4 \mathrm{~mm}$ in SM, where the number of shoots was higher.

The proportion of stronger shoots in any given locality was always lower in black poplar (based on average values for the three clones) compared to "NE-42" (Tab. 6), although in the most favorable soils and temperatures the differences were reduced. This shoot diameter difference is also related to the yield parameters.

\section{Total cross-sectional area of shoots (TCA)}

The TCA of all shoots was measured before the fourth harvest (Tab. 4). In locality BY there was a significantly higher average TCA in "NE-42" $\left(15.677 \mathrm{~mm}^{2}\right)$ than in the black poplar clone $210\left(5.466 \mathrm{~mm}^{2}\right)$, while in SM the average TCA values in all clones were similar, ranging from 14.063 to 15.974 $\mathrm{mm}^{2}$. In RO the best black poplar clone, 107, had an average TCA value of $7.042 \mathrm{~mm}^{2}$ and "NE-42" had an average TCA of $5.878 \mathrm{~mm}^{2}$. Just as with the leading shoot diameter, in unfavorable conditions of soil and temperature in the presence of adequate water, "NE42 " performed better than black poplar regarding TCA. Using Spearman's coefficient of rank correlation the very strong positive correlation of TCA and DMIP $\left(r_{s}=0.871, p\right.$ $<0.001)$ and moderate positive correlation of TCA and dry matter yield $\left(\mathrm{r}_{\mathrm{s}}=0.475, \mathrm{p}=\right.$ 0.001 ) was confirmed.

\section{Dry matter weight per individual plant (DMIP)}

In the locality RO, the DMIP increased almost linearly among harvests (Fig. 1c) and the increment between first and second harvest was significant in almost all clones (Tab. 3). No difference in DMIP was found among all clones in any harvest (Tab. 7). When comparing localities SM and BY after the first harvest, non-significantly higher average values for DMIP were found in all clones at the locality SM with exception of "NE-42". During the second and subsequent harvests, significantly higher average values were found in the locality SM compared to BY in all black poplar clones. By the fourth harvest, the DMIP of black polar clones in SM was twofold higher than in BY. However, the DMIP of the best black poplar clone in each locality was only significantly
Tab. 6 - Percentage of weak (diameter 10-43 $\mathrm{mm}$ ) and strong shoots $(44-95 \mathrm{~mm})$ per clone in each locality. $(\varnothing)$ : diameter $[\mathrm{mm}]$.

\begin{tabular}{|c|c|c|c|}
\hline \multirow{2}{*}{ Locality } & \multirow{2}{*}{ Clone } & \multicolumn{2}{|c|}{ Percentage of shoots } \\
\hline & & $\varnothing 10-43 \mathrm{~mm}$ & $\varnothing 44-95 \mathrm{~mm}$ \\
\hline \multirow[t]{2}{*}{$\mathrm{BY}$} & clones of black poplar & 95.3 & 4.7 \\
\hline & $\mathrm{NE}-42$ & 61.5 & 38.5 \\
\hline \multirow[t]{2}{*}{ SM } & clones of black poplar & 89.6 & 10.4 \\
\hline & $\mathrm{NE}-42$ & 82.4 & 17.6 \\
\hline \multirow[t]{2}{*}{ RO } & clones of black poplar & 80.8 & 19.2 \\
\hline & NE-42 & 76.3 & 23.7 \\
\hline
\end{tabular}

lower than "NE-42" for the second and fourth harvests at the BY site.

\section{Biomass production}

"NE-42" gave the highest biomass yields in each of the four harvests in each of the three sites (Tab. 8). During the fourth harvest the difference in biomass produced by "NE-42" and the best black poplar clone was signifi- cant in sites BY and SM. However, in locality RO the yield from clone 107 during the fourth harvest was not significantly different, $\mathrm{yr}^{-1}$. In the locality BY the black poplar yields were low and showed no significant differences in growth from the the second to the fourth harvest (Tab. 3). In the SM site yields from the second harvest onwards were being $13.2 \mathrm{t} \mathrm{ha}^{-1} \mathrm{yr}^{-1}$ compared to $15.9 \mathrm{t} \mathrm{ha}^{-1}$

Tab. 7 - Dry matter weight of individual plants $\left[\mathrm{kg} \mathrm{yr}^{-1}\right]$ for each harvest.

\begin{tabular}{|c|c|c|c|c|c|c|c|}
\hline \multirow{2}{*}{ Rotation } & \multirow{2}{*}{ clone } & \multicolumn{2}{|r|}{ BY } & \multicolumn{2}{|r|}{ SM } & \multicolumn{2}{|r|}{ RO } \\
\hline & & $\mathbf{N}$ & mean $\pm \mathrm{SE}$ & $\mathbf{N}$ & mean $\pm \mathrm{SE}$ & $\mathbf{N}$ & $\operatorname{mean} \pm \mathrm{SE}$ \\
\hline \multirow[t]{4}{*}{ I rotation } & 107 & 2 & $0.14 \pm 0.00^{\mathrm{a}}$ & 4 & $0.54 \pm 0.10^{\mathrm{a}}$ & 5 & $0.94 \pm 0.12^{a}$ \\
\hline & 210 & 4 & $0.34 \pm 0.08^{\mathrm{a}}$ & 4 & $0.57 \pm 0.07^{\mathrm{a}}$ & 5 & $1.05 \pm 0.10^{\mathrm{a}}$ \\
\hline & 301 & 3 & $0.19 \pm 0.02^{\mathrm{a}}$ & 4 & $0.43 \pm 0.04^{\mathrm{a}}$ & 1 & $0.69^{\mathrm{a}}$ \\
\hline & NE-42 & 4 & $0.63 \pm 0.22^{\mathrm{a}}$ & 4 & $0.48 \pm 0.09^{\mathrm{a}}$ & 5 & $1.16 \pm 0.09^{\mathrm{a}}$ \\
\hline \multirow[t]{4}{*}{ II rotation } & 107 & 2 & $0.99 \pm 0.49^{b}$ & 4 & $3.01 \pm 0.34^{\mathrm{a}}$ & 5 & $1.45 \pm 0.08^{a}$ \\
\hline & 210 & 4 & $1.00 \pm 0.23^{b}$ & 4 & $3.29 \pm 0.15^{\mathrm{a}}$ & 5 & $1.61 \pm 0.09^{\mathrm{a}}$ \\
\hline & 301 & 3 & $1.54 \pm 0.24^{b}$ & 4 & $3.57 \pm 0.62^{a}$ & 5 & $1.44 \pm 0.25^{\mathrm{a}}$ \\
\hline & NE-42 & 4 & $4.41 \pm 0.40^{\mathrm{a}}$ & 4 & $4.24 \pm 0.45^{\mathrm{a}}$ & 5 & $2.34 \pm 0.31^{\mathrm{a}}$ \\
\hline \multirow[t]{4}{*}{ III rotation } & 107 & 1 & $3.22^{\mathrm{a}}$ & 4 & $4.37 \pm 0.33^{a b}$ & 5 & $2.33 \pm 0.27^{\mathrm{a}}$ \\
\hline & 210 & 4 & $1.81 \pm 0.19^{\mathrm{a}}$ & 4 & $3.59 \pm 0.23^{b}$ & 4 & $1.98 \pm 0.15^{\mathrm{a}}$ \\
\hline & 301 & 3 & $2.61 \pm 0.45^{\mathrm{a}}$ & 4 & $4.50 \pm 0.38^{a b}$ & 5 & $1.90 \pm 0.31^{\mathrm{a}}$ \\
\hline & NE-42 & 4 & $4.23 \pm 0.99^{a}$ & 4 & $5.15 \pm 0.17^{\mathrm{a}}$ & 5 & $2.64 \pm 0.63^{\mathrm{a}}$ \\
\hline \multirow[t]{4}{*}{ IV rotation } & 107 & 2 & $2.24 \pm 0.69^{b}$ & 4 & $4.72 \pm 0.33^{a b}$ & 5 & $2.90 \pm 0.31^{\mathrm{a}}$ \\
\hline & 210 & 4 & $1.45 \pm 0.26^{b}$ & 4 & $3.62 \pm 0.32^{\mathrm{c}}$ & 3 & $2.59 \pm 0.25^{\mathrm{a}}$ \\
\hline & 301 & 3 & $2.30 \pm 0.19^{b}$ & 4 & $4.31 \pm 0.10^{b c}$ & 3 & $2.56 \pm 0.93^{a}$ \\
\hline & NE-42 & 4 & $5.52 \pm 1.02^{a}$ & 4 & $5.30 \pm 0.05^{\mathrm{a}}$ & 5 & $3.29 \pm 0.70^{\mathrm{a}}$ \\
\hline
\end{tabular}

Tab. 8 - Total dry matter yields per unit area $\left[\mathrm{t} \mathrm{ha}^{-1} \mathrm{yr}^{-1}\right]$ in black poplar clones and in the hybrid clone "NE-42"; expressed with respect to the percentage of surviving plants.

\begin{tabular}{|c|c|c|c|c|c|c|c|}
\hline \multirow{2}{*}{ Rotation } & \multirow{2}{*}{ Clone } & \multicolumn{2}{|r|}{ BY } & \multicolumn{2}{|r|}{ SM } & \multicolumn{2}{|r|}{ RO } \\
\hline & & $\mathbf{N}$ & mean $\pm \mathrm{SE}$ & $\mathbf{N}$ & mean $\pm \mathrm{SE}$ & $\mathbf{N}$ & mean $\pm \mathrm{SE}$ \\
\hline \multirow[t]{4}{*}{ I rotation } & 107 & 2 & $0.3 \pm 0.0^{\mathrm{a}}$ & 4 & $1.1 \pm 0.1^{\mathrm{a}}$ & 5 & $6.5 \pm 0.8^{\mathrm{ab}}$ \\
\hline & 210 & 4 & $0.8 \pm 0.2^{\mathrm{a}}$ & 4 & $1.3 \pm 0.2^{\mathrm{a}}$ & 5 & $7.5 \pm 0.7^{a b}$ \\
\hline & 301 & 3 & $0.3 \pm 0.1^{\mathrm{a}}$ & 4 & $0.9 \pm 0.1^{\text {a }}$ & 1 & $4.3^{b}$ \\
\hline & NE-42 & 4 & $1.4 \pm 0.5^{\mathrm{a}}$ & 4 & $1.0 \pm 0.2^{\mathrm{a}}$ & 5 & $8.3 \pm 0.7^{\mathrm{a}}$ \\
\hline \multirow[t]{4}{*}{ II rotation } & 107 & 2 & $1.9 \pm 1.4^{\mathrm{b}}$ & 4 & $6.7 \pm 0.8^{a}$ & 5 & $8.7 \pm 1.0^{\mathrm{a}}$ \\
\hline & 210 & 4 & $2.2 \pm 0.5^{b}$ & 4 & $7.3 \pm 0.3^{\mathrm{a}}$ & 5 & $10.9 \pm 0.4^{\mathrm{a}}$ \\
\hline & 301 & 3 & $2.7 \pm 0.5^{b}$ & 4 & $7.6 \pm 1.6^{a}$ & 5 & $9.8 \pm 1.5^{\mathrm{a}}$ \\
\hline & NE-42 & 4 & $9.8 \pm 0.9^{\mathrm{a}}$ & 4 & $9.4 \pm 1.0^{\mathrm{a}}$ & 5 & $15.4 \pm 1.8^{\mathrm{a}}$ \\
\hline \multirow[t]{4}{*}{ III rotation } & 107 & 1 & $7.2^{\mathrm{a}}$ & 4 & $9.7 \pm 0.7^{a b}$ & 5 & $13.4 \pm 1.0^{\mathrm{a}}$ \\
\hline & 210 & 4 & $3.8 \pm 0.5^{\mathrm{a}}$ & 4 & $8.0 \pm 0.5^{b}$ & 4 & $9.6 \pm 1.1^{\mathrm{a}}$ \\
\hline & 301 & 3 & $4.1 \pm 0.2^{a}$ & 4 & $9.5 \pm 1.0^{a b}$ & 5 & $10.5 \pm 1.7^{\mathrm{a}}$ \\
\hline & NE-42 & 4 & $9.1 \pm 2.4^{\mathrm{a}}$ & 4 & $11.4 \pm 0.4^{\mathrm{a}}$ & 5 & $18.9 \pm 3.7^{\text {a }}$ \\
\hline \multirow[t]{4}{*}{ IV rotation } & 107 & 2 & $3.7 \pm 2.8^{b}$ & 4 & $9.9 \pm 0.5^{b}$ & 5 & $13.2 \pm 3.0^{\mathrm{ab}}$ \\
\hline & 210 & 4 & $2.5 \pm 0.5^{b}$ & 4 & $8.0 \pm 0.7^{\mathrm{c}}$ & 4 & $5.4 \pm 1.2^{\mathrm{ab}}$ \\
\hline & 301 & 3 & $3.3 \pm 0.5^{b}$ & 4 & $9.1 \pm 0.6^{\mathrm{bc}}$ & 2 & $3.2 \pm 1.2^{b}$ \\
\hline & NE-42 & 4 & $11.7 \pm 2.6^{\mathrm{a}}$ & 4 & $11.8 \pm 0.1^{\mathrm{a}}$ & 5 & $15.9 \pm 4.1^{\mathrm{a}}$ \\
\hline
\end{tabular}


significantly greater and gradually increased over time, even though the differences were not statistically significant. Only in clone 107 was the yield significantly increased from the second to the third harvest in SM and RO (Tab. 3). In this clone, as in "NE42 ", the strong shoots made up a significan proportion of the TCA. In "NE-42" after the second harvest biomass did not significantly increase. During the first two harvests in RO the yields of all clones were much higher than in the other two locations, which can be explained by the higher initial planting densities and, during the first harvest, also the higher individual plant weights. In subsequent harvests the yields increased less rapidly and during the fourth harvest in all clones yields actually fell (Fig. 1d), due to high mortality.

\section{Discussion}

The interaction of environmental conditions on yield traits and biomass produced by black poplar compared to the hybrid clone "NE-42" was evaluated at three localities. Differing natural conditions in these sites allowed the study of a wide range of reactions of the individual genotypes. Two localities represented marginal areas in the distribution of black poplar, where the planting of allochthonous species is usually not allowed (e.g., national parks). In these situations it is anticipated that only pure clones of black poplar will be grown in SRC systems The third locality represents flood plain areas which are suitable for growing black poplar because it is tolerant of long-term flooding (Mottl 1989).

The hybrid "NE-42" showed higher yield than the most productive black poplar clone in all three environments. It must be said, however, that this hybrid clone is the result of a selection process involving several thousand seedlings derived from planned crossings (Stout \& Schreiner 1933), while the black poplar clones were chosen from a group of 200 individuals collected from wild populations (Benetka et al. 2007). However, several new clones of black poplar now exist which are the result of deliberate crossings, and in early trials have given higher yields than "NE-42" (Benetka et al. 2012), so black poplar clones with satisfactory yield potential are expected to be available soon.

In the locality with a low average temperature and low $\mathrm{pH}$, and nutrient-poor peaty soils (BY), the black poplar clones had low yields, while "NE-42" achieved yields comparable to those in locality SM with its medium quality soils and higher average annual temperatures. In these more favorable conditions the yields of the best black poplar clones approached those of "NE-42". In the most favorable conditions (locality RO), there was no significant difference between the yields of the best black poplar clones and the hybrid. This means that black poplar did not perform well only in the very unfavorable conditions regarding soils and temperatures, while "NE-42" demonstrated greater adaptability and performed well even under unfavorable conditions. It would appear that here the character of one of the parent species (Populus trichocarpa) is being expressed (Smith 1957).

Total yields per unit area are determined by the number of plants per unit area and the weight of individual plants. The initial numbers of plants falls over time due to mortality, although observed mortality was lower than in stands with higher initial plant densities (Laureysens et al. 2005). The effect of varying initial plant densities on subsequent mortality was observed in our experiment also.

The weight of individual plants is positively correlated with various component parameters such as height, thickness and the number of shoots (Pontailler et al. 1997, Rae et al. 2004, Benetka et al. 2007). As has been shown, height is correlated with thickness of the main stem (Nelson et al. 1981), and so only one of these parameters needs to be measured in order to estimate yields. Differences in the thickness of stems between "NE-42" and the black poplar clones was less pronounced in the more favorable growing conditions. The number of shoots increased during the four harvests in this study, although the number of shoots regenerating from the cut stumps also depends on the amount of light, which is in turn affected by plant density (Atwood et al. 2008). Competition between shoots for light during canopy closure is believed to affect stool survival (Dillen et al. 2011). The poplar genotypes differ with regard to their light-use efficiency and so also in the extent to which their photosynthesis is optimized in dense canopies (Green et al. 2001).

Even though the weight of individual plants was great in locality SM, the amount of biomass yield per hectare was not corresponding with it. The maximum yield of biomass was probably limited here by the overall low density of plants, as reported by Enquist et al. (2009) and Weiner \& Freckleton (2010).

In comparing the yield potential of the hybrid "NE-42" and the best black poplar clones used in these trials, it can be supposed that black poplar can be successfully grown even in marginal areas for the natural occurrence of black poplar, that is, in areas with low average temperatures and less fertile soils, but not however in areas with low temperatures and peaty soils (Mottl \& Dušek 1991), where the hybrid clone "NE-42" is more successful.

The TCA measured just before the fourth harvest was highly correlated with DMIP and also correlated with the yield of biomass on individual plots. As early as the second harvest a correlation was confirmed between the number of shoots and also the thickness of the main shoot and biomass yields (Benetka et al. 2007). The correlation between the height of plants, thickness of shoots and other parameters and biomass yields is wellknown from many studies and has been used for the non-destructive estimation of total biomass (Zianis et al. 2005, Felix et al. 2008). These correlations could be used to estimate DMIP and biomass yields during the selection process in breeding programs, when the first selection is made on the basis of visual assessments. However, breeding programs must also take into account resistance to important diseases, principally the leaf rust Melampsora larici-populina, which can significantly lower final yields (Benetka et al. 2011a) with its damaging effects on plant growth (Nelson et al. 1981), affecting the amount of light penetrating the canopy and so the competition among plants.

It can be concluded that in the selection of new black poplar clones it is important to consider the genotypes which produce thick, strong shoots rather than large numbers of weaker shoots, even though black poplar yields tend to be based on the production of large numbers of weaker shoots (Laureysens et al. 2005). The possibility of successfully making such a selection in black poplar is confirmed by the marked genetic diversity evident in the number and strength of its shoots (Benetka et al. 2012).

\section{Conclusions}

The three best black poplar clones planted in three different sites had in all four harvests a lower yield than the hybrid clone "NE-42" which was used as a standard for comparison. These differences were less marked in the locality with better natural growing conditions and were not significantly different at the site with the most favorable growing conditions. The higher yield of the hybrid clone is evidently related to the fact that it has been produced by selecting from the progeny of an interspecific cross, in which the aim was to take advantage of the phenomenon of hybrid vigor. The black poplar clones, however, were derived by taking material from a wild population and were not the product of any kind of selective breeding program. These clones showed less adaptability to unfavorable temperature and soil conditions compared to "NE-42", whose greater adaptability can be attributed to the characteristics of one of its parent species, $P$. trichocarpa.

A clear correlation was shown between the total cross-sectional area of shoots on the one hand and the dry weight of individual plants and the dry weight of harvested biomass on the other. This relationship could prove useful when making the first selection 
in any breeding program designed to produce higher performing clones of black poplar.

\section{Acknowledgments}

This research was financially supported by project no. 2B06131 of the Czech Ministry of Education, Youth and Sports and institutional support (VUKOZ-IP-00027073). The authors gratefully acknowledge the help provided by Malcolm Russell with the English.

\section{References}

Al Afas N, Marron N, Van Dongen S, Laureysens I, Ceulemans R (2008). Dynamics of biomass production in a poplar coppice culture over three rotations (11 years). Forest Ecology and Management 255: 1883-1891. - doi: 10.1016/j.foreco. 2007.12.010

Atwood CJ, Fox TR, Loftis DL (2008). Stump sprouting of oak species in three silvicultural treatments in the southern Appalachians. In: Proceedings of the " $16^{\text {th }}$ Central Hardwoods Forest Conference" (Jacobs DF, Michler CH eds). West Lafayette (Indiana, USA) 8-9 April 2008, pp. 27.

Benetka V, Vacková K, Bartáková I, Pospíšková M, Rasl M (2002). Introgression in black poplar (Populus nigra L. ssp. nigra) and its transmission. Journal of Forest Science 48: 115-120.

Benetka V, Vrátný F, Šálková I (2007). Comparison of the productivity of Populus nigra L. with an interspecific hybrid in a short rotation coppice in marginal areas. Biomass and Bioenergy 31: 367-374. - doi: 10.1016/j.biombioe.2007.01.005 Benetka V, Cerný K, Pilarová P, Kozlíková K (2011a). Effect of Melampsora larici-populina on growth and biomass yield of eight clones of Populus nigra. Journal of Forest Science 57: 4149.

Benetka V, Kozlíková K, Štochlová P (2011b). New clones of black poplar (Populus nigra L.) for short station coppice cultures. Acta Pruhoniciana 97: 33-38. [in Czech].

Benetka V, Novotná K, Štochlová P (2012). Wild populations as a source of germplasm for black poplar (Populus nigra L.) breeding programmes. Tree Genetics and Genomes 8: 1073-1084. - doi: 10.1007/s11295-012-0487-6

Bisoffi S, Gullberg U (1996). Poplar breeding and selecion strategies. In: "Biology of Populus and its implications for management and conservation" (Stettler RF, Bradshaw Jr HD, Heilman PE, Hinckley TM eds). NRC Research Press, National Research Council of Canada, Ottawa, ON, Canada, pp. 139-158.

Cagelli L, Lefèvre F (1995). The conservation of Populus nigra L. and gene flow with cultivated poplars in Europe. Forest Genetics 2: 135-144.

Ceulemans R, Deraedt W (1999). Production physiology and growth potential of poplars under short-rotation forestry culture. Forest Ecology and Management 121: 9-23. - doi: 10.1016/
S0378-1127(98)00564-7

Dickmann DI, Kuzovkina J (2008). Poplars and willows in the World. Chapter 2, Working paper IPC/9-2, FAO, Rome, Italy, pp. 134

Dillen SY, Vanbeveren S, Al Afas N, Laureysens I, Croes S, Ceulemans R (2011). Biomass production in a 15-year-old poplar short-rotation coppice culture in Belgium. In: "Aspects of Applied Biology 112: Biomass and Energy Crops IV". Association of Applied Biologists, Wellesbourne, UK, pp. 99-106.

Di Matteo G, Sperandio GG, Verani S (2012). Field performance of poplar for bioenergy in southern Europe after two coppicing rotations: effects of clone and planting density. iForest 5: 224-229. - doi: 10.3832/ifor0628-005

Enquist BJ, West GB, Brown JH (2009). Extensions and evaluations of a general quantitative theory of forest structure and dynamics. Proceedings of the National Academy of Sciences USA 106: 7046-7051. - doi: 10.1073/pnas.08123031 06

Felix E, Tilley DR, Felton G, Flamino E (2008). Biomass production of hybrid poplar (Populus spp.) grown on deep-trenched municipal biosolids. Ecological Engineering 33: 8-14. - doi: 10.1016/j.ecoleng.2007.10.009

Green DS, Kruger EL, Stanosz GR, Isebands JG (2001). Light-use efficiency of native and hybrid poplar genotypes at high levels of intracanopy competition. Canadian Journal of Forest Research 31: 1030-1037. - doi: 10.1139/x01-041

Herve C, Ceulemans R (1996). Short-rotation coppiced vs. non-coppiced poplar: a comparative study at two different field sites. Biomass and Bioenergy 11: 139-150. - doi: 10.1016/0961-95 34(96)00028-1

Karp A, Hanley SJ, Trybush SO, Macalpine W, Pei M, Shield I (2011). Genetic improvement of willow for bioenergy and biofuels. Journal of Integrative Plant Biology 53: 151-165. - doi: 10.11 11/j.1744-7909.2010.01015.x

Langeveld H, Quist-Wessel F, Dimitriou I, Aronsson P, Baum C, Schulz U, Bolte A, Baum S, Köhn J, Weih M, Gruss H, Leinweber P, Lamersdorf N, Schmidt-Walter P, Berndes G (2012). Assessing environmental impact of short station coppice (SRC) expansion: model definition and preliminary results. Bioenergy Research 5: 621-635. - doi: 10.1007/s12155-012-9235-X

Laureysens I, Pellis A, Willems J, Ceulemans R (2005). Growth and production of a short rotation coppice culture of poplar. III. Second rotation results. Biomass and Bioenergy 29: 10-21. doi: 10.1016/j.biombioe.2005.02.005

Mottl J (1989). Poplars and their use in energy. Aktuality RIOG, Pruhonice, Czech Republic, pp. 204. [in Czech]

Mottl J, Dušek J (1991). Specification of growing areas of poplars for landscaping purposes. Ms Research Institute of Ornamental Gardening, Pruhonice, Czech Republic, pp. 140. [in Czech] Nelson ND, Burk T, Isebrans JG (1981). Crown architecture of short-rotation, intensively cul- tured Populus. I. Effects of clone and spacing on first-order branch characteristics. Canadian Journal of Forest Research 11: 73-81. - doi: 10. 1139/x81-010

Pontailler JY, Ceulemans R, Guittet J, Mau F (1997). Linear and non-linear functions of volume index to estimate woody biomass in high density young poplar stands. Annals of Forest Science 54: 335-345. - doi: 10.1051/forest:1997 0402

Rae AM, Robinson KM, Street NR, Taylor G (2004). Morphological and physiological traits influencing biomass productivity in short-rotation coppice poplar. Canadian Journal of Forest Research 34: 1488-1498. - doi: 10.1139/x04-033 Rogers DL, Stettler RF (1989). Genetic variation and productivity of Populus trichocarpa and its hybrids. III. Structure and pattern of variation in a 3-year field test. Canadian Journal of Forest Research 17: 415-425. - doi: 10.1139/x89-056 Smith JHG (1957). Some factors indicative of site quality for Black Cottonwood (Populus trichocarpa Torr. and Gray). Journal of Forestry 55: 578-580.

Smulders MJM, Beringen R, Volosyanchuk R, Van den Broeck A, Van der Schoot J, Arens P, Vosman B (2008). Natural hybridisation between Populus nigra L. and $P . \times$ canadensis Moench. Hybrid offspring competes for niches along the Rhine river in the Netherlands. Tree Genetics and Genomes 4: 663-675. - doi: 10.1007/s11295-008-0141-5

Stanton BJ, Neale DB, Li S (2010). Populus breeding: from the classical to the genomic approach. In: "Genetics and Genomics of Populus" (Jansson S, Bhalerao RP, Groover AT eds). Plant Genetics and Genomics: Crops and Models, Springer Science + Business Media, vol. 8, pp. 309-342.

Strong T (1989). Rotation length and repeated harvesting influence Populus coppice production. Research Note NC-350, North Central Experimental Station, USDA Forest Service, St. Paul, MN, USA, pp. 1-4.

Stout AB, Schreiner EJ (1933). Results of a project in hybridizing poplars. Journal of Heredity 24: 216-229. [online] URL: http://jhered.oxfordjournals.org/content/24/6/217.extract

Venendaal R, Jørgensen U, Foster CA (1997). European energy crops: a synthesis. Biomass and bioenergy 13: 147-185. - doi: 10.1016/S09619534(97)00029-9

Verwijst T (2001). Willows: an underestimated resource for environment and society. Forestry Chronicle 77: 281-285.

Weiner J, Freckleton RP (2010). Constant final yield. Annual Review of Ecology, Evolution, and Systematics 41: 173-192. - doi: 10.1146/annurev-ecolsys-102209-144642

Zianis D, Muukkonen P, Mäkipää R, Mencuccini $M$ (2005). Biomass and stem volume equations for tree species in Europe. Silva Fennica Monographs 4: 63 . 